\title{
Religiosity in Adolescence and Emerging Adulthood
}

\author{
Carolyn McNamara Barry \\ Loyola University of Maryland
}

Larry J. Nelson

Brigham Young University - Provo, larry_nelson@byu.edu

Follow this and additional works at: https://scholarsarchive.byu.edu/facpub

Part of the Other Social and Behavioral Sciences Commons

\section{Original Publication Citation}

Barry, C. M. \& Nelson, L. J. (2011). Religiosity in adolescence and emerging adulthood. In R. Levesque (Ed.), Encyclopedia of Adolescence, Vol 4, pp. 2239-2353. New York: Springer.

\section{BYU ScholarsArchive Citation}

Barry, Carolyn McNamara and Nelson, Larry J., "Religiosity in Adolescence and Emerging Adulthood" (2011). Faculty Publications. 4720.

https://scholarsarchive.byu.edu/facpub/4720

This Other is brought to you for free and open access by BYU ScholarsArchive. It has been accepted for inclusion in Faculty Publications by an authorized administrator of BYU ScholarsArchive. For more information, please contact ellen_amatangelo@byu.edu. 


\section{Reliability}

\author{
ROger J. R. LEVESQue \\ Indiana University, Bloomington, IN, USA
}

\section{References}

Carmines, E. G., \& Zeller, R. A. (1991). Reliability and validity assessment. Newbury Park: Sage.

Fink, A. (Ed.). (1995). How to measure survey reliability and validity. The survey kit. Vol. 7. Thousand Oaks: Sage.
Reliability refers to a measure's consistency. A measure's reliability rests on the extent to which it yields the same result on repeated trials. Reliability is of significance in that, without it, the results of research lack replicability, which is a foundation of the scientific method. Reliability cannot be calculated exactly. As a result, it is a correlation of an item, scale, or instrument with a hypothetical one that truly measures what it is supposed to. That is what is meant by calculations of reliability being estimates of reliability. There are many ways to calculate estimates, and each provides a different view of reliability.

Although there are many ways to estimate reliability, four ways are particularly common (Carmines and Zeller 1991; Fink 1995). First, internal consistency is a way to provide a reliability estimation that is based on grouping questions in a questionnaire that measure the same concept. The most common way to measure internal consistency is to use Cronbach's Alpha which, in brief, splits a measure's questions on in every possible way and computes correlation values for all of them. As with any correlation, the closer to 1 it is, the more internally reliable the measure is estimated to be. Second, split-half reliability provides reliability estimation that is based on the correlation of two equivalent forms of the scale; the Spearman-Brown coefficient typically is used to determine this type of estimate. Third, testretest reliability provides an estimation based on the correlation between multiple administrations of the same measure (or parts of it); and this method also makes use of the Spearman Brown coefficient. Lastly, inter-rater reliability is an estimation based on correlations of scores between two or more raters who answer the same measure (or parts of it). These four typical methods represent different meanings of reliability, and some studies use multiple approaches depending on what they are trying to estimate.

\section{Cross-References}

- Quantitative Methods

- Validity

\section{Religiosity in Adolescence and Emerging Adulthood}

\author{
Carolyn McNamara Barry ${ }^{1}$, Larry J. Nelson ${ }^{2}$ \\ ${ }^{1}$ Department of Psychology, Loyola University \\ Maryland, Baltimore, MD, USA \\ ${ }^{2}$ School of Family Life, Brigham Young University, \\ Provo, UT, USA
}

\section{Overview}

According to IEA Civic Education Study, approximately half of American adolescents participate in religious groups (Torney-Purta et al. 2001) and half of American 18-24-year-olds report religious beliefs to be important (Inglehart et al. 2004). Thus, religious experiences are an important aspect of the lives of many adolescents and emerging adults (approximately ages 18 to the mid-20s) in the USA. Specifically, adolescents are fully immersed in identity exploration and ideally resolve this search in emerging adulthood. They embark on a quest to solidify their values and beliefs about countless issues, including religiosity. This essay will review the literature on religiosity among adolescents and emerging adults. First, terms are defined and then the developmental underpinnings that support young people's religiosity are discussed. Next, theories and empirical work on religious development are articulated. Thereafter, literature on prevalence rates of religiosity and their psychological and behavioral correlates are reviewed. Then, research on the socializing agents of religiosity is summarized followed by a discussion of individual and group differences in religiosity. The essay concludes with future directions for scholarship and implications.

\section{Definitions}

Although the essay examines religiosity, it is important to note its conceptual relatedness to spirituality. While scholars agree on the multifaceted nature of both 
constructs (e.g., Moberg 2002), they disagree as to which is broader (for a review, see Zinnbauer and Pargament 2005). Nevertheless, there is an increasing subgroup of spiritual, but not religious people; subgroups of religious, but not spiritual appear uncommon (Zinnbauer et al. 1999). In the current essay, Miller and Thoresen's (2003) approach is utilized, such that religiosity encompasses organized and institutional aspects, and is best represented by individual beliefs and practices. In contrast, spirituality encompasses personal and transcendent aspects.

\section{Developmental Considerations}

Beginning in adolescence, young people often reflect upon their religious beliefs and practices, which ideally results in a sophisticated self-understanding of beliefs by the end of emerging adulthood (Braskamp 2008). This gradual process is supported by the biological, cognitive, and psychosocial changes in development during this time. Puberty marks the beginning of a transition toward adult biological functioning that concludes at the onset of emerging adulthood. As others perceive young people's bodies to be adult-like, they increasingly adopt adult roles and perceive themselves as adults (Dorn et al. 2006). By the time they indicate themselves to be adults, most are nearing the end of emerging adulthood and typically have resolved much of their identity development (Nelson and Barry 2005).

Amidst these pubertal changes, synaptic pruning, myelination of the prefrontal cortex, and changes in the limbic system occur within the brain from early adolescence into the early twenties (Sowell et al. 2002; Steinberg 2005). Given the reorganization of the prefrontal cortex, young people are able to plan, engage in metacognition, and think increasingly about abstract concepts (e.g., Is there a God?; Labouvie-Vief 2006). Further, changes in the limbic system's hormones and neurotransmitters result in greater emotional responsiveness to stress (Walker et al. 2004), leading many young people to use coping mechanisms such as religiosity (Young et al. 2000).

These biological and cognitive advances support self-exploration about issues including religiosity (Waterman 1985). These greater levels of cognitive flexibility allow for more careful consideration of phenomenon claiming multiple truths and provide adolescents with the ability to organize their self-awareness of a range of feelings into a coherent cognitive structure. Moreover, adolescents' exploration is aided as their dualistic thinking becomes pragmatic by emerging adulthood (Perry 1981). As one's identity moves toward resolution, young people's principled and abstract cognition supports their commitment to and internalization of religion (Elkind 1978).

Along with physical and cognitive changes, psychosocial changes occur. According to Eriksonian theory (1968) and recent research, as adolescents progress in their identity development they increasingly seek out and experience more emotionally intimate relationships with friends and romantic partners (e.g., Beyers and Seiffge-Krenke 2008). As a result, peer relationships are important contexts wherein religious beliefs and practices can be modeled and potentially influence young people. Indeed, most college students' religious experiences and discussions occur with friends (Montgomery-Goodnough and Gallagher 2007). Given the normative changes in schooling (grade levels, classes, different institutions) for young people as well as residential and job changes among emerging adults, friendship groups and romantic partners are likely to fluctuate, thereby changing the composition of these peer contexts (e.g., Arnett 2004). Thus, these potential socialization agents of young people's religiosity are not static. Taken together, adolescents and emerging adults experience physical, cognitive, and psychosocial changes that undergird religious development, which occurs through a process of young people increasingly owning their own values and beliefs.

\section{Religious Development}

Three theoretical approaches for religious development exist (Levesque 2002). First, people utilize rules that frame how they relate to a higher power. This religious consciousness results through daily prayer or participation in a religious community (e.g., Tamminen 1994). These experiences thereby contribute to religious beliefs and judgment, which in turn promote the formation of a deep mother-structure concerning religious issues. This structure's content is shaped by contexts, peoples, and experiences, and becomes increasingly complex and connected to a person's larger cognitive structures of beliefs.

Second, faith is viewed as what people center their lives on according to Fowler (2001), and not how they conceptualize a relationship to a higher power. This process of meaning-making does, however, occur in 
a step-wise sequence and incorporates cognitive development. According to Fowler and Dell (2006), adolescents form a synthetic-conventional faith, wherein they maintain a strong sense of beliefs and values, even if contradictory. Adolescents are not as sophisticated in critical thinking and articulation of their beliefs and values as they will become. Over the course of adulthood, people may or may not keep their faith and beliefs of their childhood as they form an individuative-reflective faith. Over time, adults may come to reconcile paradoxical beliefs surrounding religion to form a conjunctive faith. Lastly, they may relate to a higher power by incorporating holistic beliefs concerning creation to form a universalizing faith.

Third, Elkind (1971) emphasizes that individuals' faith depends upon what they are exposed to and their subsequent cognitive interpretations of it. This model integrates socialization influences with cognition and focuses on how children come to internalize values and morals. The three theoretical approaches provide a normative description of religious beliefs' change, and lay the groundwork from which a young person could form a religious institutional attachment as well as, or instead, their religious beliefs and values (Levesque 2002).

In addition to these three perspectives, religious development has been conceptualized as part of identity development. While adolescents are rarely at the same point in their identity development across domains (e.g., political vs religious; SolomontosKountouri and Hurry 2008), religious identity development in Western countries tends to begin during adolescence and proceeds toward achievement during emerging adulthood (e.g., Meeus et al. 1999) wherein identity resolution appears to be linked to greater religiosity (e.g., Duriez et al. 2008). For example, American college students who have a religious identity status of moratorium, foreclosure, or achievement report greater religious faith maturity than do those with a religious identity-diffused status (Sanders 1998).

However, doubting of one's religiosity is not necessarily negative (Puffer et al. 2008), rather it is common (O'Connor et al. 2002) and part of the process of exploring one's identity. Indeed, in some cases the identity exploration stemming from religious doubting results in religious conversion, which is most common during adolescence (Kirkpatrick 1995). According to Paloutzian (1996), conversions are quick forms of socialization. Granqvist and Kirkpatrick (2004) documented two types of religious conversions: (a) sudden and intense conversions that occur during stressful life events, and (b) gradual conversions that result from a close relationship with a religious significant other. Conversions are an important part of a subset of young people's religious development. In sum, as identity development begins in adolescence and progresses through emerging adulthood, it is likely that one's religious understanding and experience becomes more complex and may include periods of questioning, doubt, and sometimes conversion.

Taken together, the theories concerning religious development provide some framework for future work; however, greater empirical testing of these theories that utilize samples of varying ages and cultural diversity are needed. Religious identity emerges as part of the overall identity development process; greater understanding of the intersection between this domain and other identity domains is needed. Religious doubting and conversions during adolescence have been documented, but further work on how such experiences play out in emerging adulthood are needed. Next, the prevalence of religious beliefs and practices are discussed.

\section{Prevalence Rates for Religiosity}

Religious beliefs. Although religious affiliation changes for half of adolescents by emerging adulthood (Smith and Snell 2009), religion remains important to most young people. In fact, the National Study of Youth and Religion scholars followed 13-17-year-olds for 5 years, and found no real change among those with high levels of religious importance with only $8 \%$ of adolescents reporting a decline in importance by emerging adulthood. While $78 \%$ of American emerging adults (18-23-year-olds) are theists, $7 \%$ of those theists as adolescents report being unsure or atheists as emerging adults. Only a subset of nonreligious adolescents reported increases in faith as emerging adults. Within emerging adulthood, however, recent research documents stability of religious beliefs, if not an increase. Studying a national sample of American first-year university students over 4 years, Lee (2002) found that $37.9 \%$ strengthened their religious convictions and beliefs, $48.3 \%$ reported no change, and $13.7 \%$ weakened over time (see also Smith and Snell 2009). 
Religious beliefs change in importance, but also in content. In summarizing the NSYR study, Smith and Denton (2005) contended that most adolescents ascribe to what they called "moralistic therapeutic deism" (MTD). While not abandoning their religious affiliation, these adolescents' beliefs became less dogmatic and more humanistic; they viewed God as creator, promoter of goodness and fairness, yet peripheral to their daily lives unless a problem arose. Moreover, they deem all good people to enter heaven upon their death and that life's purpose is happiness and having self-worth.

By emerging adulthood, Smith and Snell (2009) noted that MTD is still present, but more diluted for emerging adults. As beliefs become more solidified, they also become more individualized. For example, $71 \%$ of American 21-28-year-olds claimed to be certain about their religious beliefs, even though their beliefs often were individualistic and less doctrine based (Arnett and Jensen 2002), as represented by greater belief in astrology, and less belief in judgment day (Smith and Snell 2009). Moreover, they became increasingly "spiritual, but not religious" and less tolerant of others promoting religious conversions. In sum, while religious beliefs change and in some cases decline across adolescence into emerging adulthood, young people do not abandon or radically alter their beliefs; rather they tailor them to fit their own identity.

Religious practices. Whereas religious beliefs decline somewhat, religious practices decline more precipitously from early adolescence until the first few years of emerging adulthood (Koenig et al. 2008). Following 7th-12th grade American adolescents until the age of 18 to 25 , Uecker et al. (2007) documented a drop by $69 \%$ in religious service attendance during emerging adulthood. While not as drastic, other types of religious practices decline during this transition: $8 \%$ fewer emerging adults pray alone daily and $12 \%$ fewer performed in a religious music group (Smith and Snell 2009). As with beliefs, nonreligious adolescents were the sole group who increased in religious practices by emerging adulthood. In sum, while individuals' religious beliefs recover somewhat by the end of emerging adulthood, religious practices decline without an upswing until young people marry and have children in their late twenties and early thirties (Stolzenberg et al. 1995).

\section{Correlates of Religiosity}

Adolescents' and emerging adults' religiosity has been associated with adjustment, including high self-esteem (Rew and Wong 2006) and civic engagement (Park and Smith 2000). Additionally, religiosity is associated with lower risk preference (Miller 2000), and in turn reduced engagement in risk behaviors (White et al. 2006) by promoting adolescents' developmental assets (Wagener et al. 2003).

Religiosity also has been associated with some negative outcomes. For instance, the minority of highly religious, yet sexually active emerging adults have increased rates of unsafe sex (Zaleski and Schiaffino 2000). Most religious communities do not endorse sexual minority's lifestyles (Finlay and Walther 2003). In some extreme cases, religiosity (e.g., Satanism) has been associated with negative mental and physical health (Koenig et al. 2001). Thus, further research into these exceptions is needed. To understand the relation between religiosity and adjustment better, the role of socializing agents is considered next.

\section{Socializing Agents}

Research has shown that social influences, especially family factors, play a much larger role than genetics in adolescents' religious beliefs and practices (Eaves et al. 2008). Given that $90 \%$ of parents report wanting religious training for their children (Gallup and Casteli 1989), parents are children's primary religious socializers, while other adults, peers, and media are also important. Indeed, agents may play different roles at different ages. Parents' influence shifts from being more direct during adolescence to indirect during emerging adulthood, whereas other adults, peers, and the media shift from more indirect to direct during these times.

Parents. According to NSYR data (Smith and Denton 2005), the majority of American adolescents tend to be like their parents with respect to (a) sharing similar religious beliefs, (b) being situated in the same general religious traditions, and (c) attending religious service at similar frequency. Also, they found that adolescents' religious faith and practices tend to be influenced by aspects of parent religiosity (e.g., religious beliefs, attending religious services), parenting (e.g., parental warmth, parenting styles), the parentchild relationship, and general family socialization practices (e.g., attending church with children). While 
it is often difficult to disentangle each of these from one another, this section specifies each of these ways in which parents might socialize their children in religion.

Parental religiosity. Parents' own religiosity appears to play an important role in young people's lives including health benefits and higher educational attainment (e.g., Caputo 2004). Parental religiosity also has been connected to their children's religious development directly. Concerning affiliation, Nelson (1990) found that nearly all adolescents report a religious affiliation when both parents do or even if just mothers do. Beyond affiliation, parents' religious importance and practices agreed with adolescents' own religious importance and practices (Bao et al. 1999; Smith and Denton 2005).

It has been argued that the effects of parental religiosity diminish in emerging adulthood (see Arnett and Jensen 2002). However, these findings may simply point to a decline in the link between parental religiosity and both practices and specific beliefs, because there is evidence that some association between parent and child religiosity still exists (e.g., Smith and Denton 2005). Furthermore, adolescents' report of parental religiosity was the strongest predictor of emerging adults' religiosity (Smith and Snell 2009). Thus, parental religiosity does not diminish completely, but rather can play a clear role in emerging adults' socialization.

Socialization mechanisms. Having documented the direct effects of parental religiosity on their children's religiosity, the essay next explores the mechanisms by which parents socialize their children's religiosity. First, theory (Oman and Thoresen 2003) and research (e.g., Flor and Knapp 2001) suggest that children engage in "observational spiritual learning," in which they learn through observing other persons (i.e., parents) who are their "spiritual models" (Silberman 2003). Second, family religious practices may serve as another socialization mechanism through which parents influence their children. Some forms of family religious practices that distinguish religious affiliation, strength of religious beliefs, and engagement in young people's religious practices include religious discussions with parents (Dollahite and Thatcher 2008), praying at family meals (Loser et al. 2009), and reading sacred texts as a family (Nelson et al. 2010).

In sum, parents serving as spiritual models and family practices surrounding religion appear to play substantial roles in how parents socialize their religious and spiritual beliefs to their children. Of course, there are numerous factors related to how and whether these socialization mechanisms successfully convey beliefs. For example, in studying the discussions that adolescents have with their parents regarding religion, Dollahite and Thatcher (2008) note that content (e.g., religious teachings, life situations), structure (e.g., formal or informal discussions), location (e.g., at home, in the car), and frequency all impact these discussions. Furthermore, they found that the emotional climate of the conversation (e.g., adolescents get to talk more than parents) fostered by the parent influences the effectiveness of the modeling and family practices. Hence, next the essay will focus on parenting and the parent-child relationship to underscore the processes involved in how effective these socialization processes are.

Parenting. Work on the effects of parenting on young people's religiosity has focused on specific aspects of parenting. For example, emerging adults who perceived coercive techniques for parental socialization (e.g., forced church attendance) were less likely to report church involvement in adulthood (Hoge et al. 1993). Unfortunately, this work typically did not account for both parent religiosity and parenting. More recently, research has documented a link between religiosity and (in most cases) more adaptive parenting, see Mahoney et al. (2001) for a review. This has led, however, to a debate about whether the positive outcomes associated with parental religiosity are really just the effects of positive parenting. Gunnoe and Moore (2002) found that presence of religious models (especially religious mothers who engaged in authoritative parenting) during childhood and adolescence best predicted American emerging adults' religiosity. Finally, Bao et al. (1999) documented that the relation between parent religiosity and child outcomes may be moderated by the way in which children are parented, such that the links between parents' and adolescents' religious beliefs and practices diminished when parental acceptance was low and increased when it was moderate or high. In sum, these results provide evidence that how parents "package" (i.e., acceptance vs force) their religious beliefs may be a determining factor in whether children are likely to receive and accept them. Positive parenting may also enhance the overall relationship that has also been found to enhance young people's religious development. 
Parent-child relationship. The parent-child relationship may serve as a mechanism of religious socialization. For example, adolescents with more secure attachments are more likely to hold similar religious beliefs to their parents (Granqvist and Hagekull 1999). According to Smith and Denton (2005), the most religiouslydevoted adolescents reported their parents to be more understanding, loving, and attentive to them than their less religiously devoted peers. Similar findings exist in emerging adulthood. Specifically, when emerging adults and their mothers report higher levels of spiritual disclosure, they also tend to experience higher levels of relationship satisfaction, conflict resolution strategies, and general disclosure (Brelsford and Mahoney 2008). Similarly, Milevsky and Leh (2008) found that both mother and father support was related to emerging adults' religious activity and importance.

Taken together, there is evidence to support Smith and Snell's claim that "who and what parents were and are for their children when it comes to religious faith and practice are much more likely to 'stick' with them, even into emerging adulthood, than who and what their teenage friends were" (p. 285). Nevertheless, future work is needed to examine aspects of parenting (e.g., parents' religiosity, parenting styles, parent-child relationships) as direct influences as well as mediating factors in accounting for individual differences in emerging adults' religiosity. Given that marital dynamics as well as sibling relationship quality have been found to be related to emerging adults' religiosity (Milevsky et al. 2005), scholars should examine other familial aspects as well.

Other adults. While they certainly play an important role, parents may not be the only adults who influence their children's religious development. Smith and Denton (2005) found that most American adolescents who attend a congregation have nonfamilial adults in their congregation with whom they enjoy talking and who give lots of encouragement. For the minority who did not have such an adult, $61 \%$ indicated a desire for one. Among certain subgroups of the most highly religious youth (e.g., Mormons), as many as $90 \%$ of those youth (compared to $53 \%$ average) reported having adults (nonfamily) in the congregation with whom they enjoy talking with and who encourage them (Smith and Denton 2005). Although it is not common across religions to have nonfamilial adults who are highly involved in religious socialization of young people, these data suggest that such roles exist and can be meaningful.

Given the decreased contact and more indirect parental influence on adolescents as they transition to adulthood, other adults with whom emerging adults interact regularly have the potential to impact them more directly (e.g., faculty influence among university students). Indeed, the college classroom does not appear to provide a setting for religious or spiritual reflection for the majority of students (Braskamp 2008). However, first-year college students who were assigned randomly to a formal mentoring program with a professor designed to nurture spiritual development self-reported greater levels of spiritual growth compared to those in a control group without a mentor (Cannister 1999). National surveys (e.g., Astin et al. 2005a, b) of American faculty and college students found that many students are seeking answers to spiritual questions and that faculty who consider themselves spiritual are more likely to be invested in students' personal development than are less spiritual faculty. Hence, it is possible that these faculty members may engage in mentoring that might include personal religiosity, thereby making meaningful contributions to students' religious and spiritual development.

Less is known about the mentors of young people who are not attending institutions of higher education. They may exist among the alternate settings within networks of extended family or parents' friends, faith communities, the military, or service opportunities (Finlay et al. 2007). Scholars should investigate the impact of these adults on emerging adults' religiosity because adults appear to matter in young people's religious and spiritual lives.

Peers. From adolescence onward, young people experience increasing levels of emotional intimacy with their friends and romantic partners (Carbery and Buhrmester 1998), and therefore may serve as important socializers. In fact, friends of primarily North American Christian adolescents provide unique additional variance beyond that of parents to adolescents' religious beliefs (Schwartz 2006), thereby suggesting a transactional model of religious socialization by both parents and peers. Consistent with countless other characteristics, friends tend to hold similar religious beliefs, especially highly religious adolescents and emerging adults (Smith and Snell 2009). Not surprisingly then, most college students' religious 
experiences and discussions occur with friends (Montgomery-Goodnough and Gallagher 2007).

Peers' religious behaviors have been predictive of adolescents' own religious behaviors (Regnerus and Smith 2005). In some cases, friends' religiosity is equal to that of parental influence on religious behaviors (e.g., joining a church youth group; De Vaus 1983), and in other cases is stronger than maternal religiosity in predicting changes in religiosity from adolescence to emerging adulthood (Gunnoe and Moore 2002). Given that parents and friends both serve as close relationships in young people's lives, scholars should investigate how both socializing contexts interact to explain young people's religiosity (see Schwartz 2006). Moreover, since the quality of relationships with romantic partners appear to matter to developmentally relevant domains in emerging adulthood (e.g., Barry et al. 2009), scholars should also investigate the more prominent role of romantic partners in socializing emerging adults' religiosity. Scholars should examine also the processes by which peers socialize each other concerning religiosity by considering the role of relationship quality and motivational constructs (see Barry and Wentzel 2006). Taken together, peers have the potential to influence adolescents' and emerging adults' religious beliefs and practices, leaving much work to be done.

Media. Because young people have less direct contact with their parents from adolescence onward (Larson and Richards 1991), and are saturated with media (Roberts et al. 1999), media may serve as an alternate socializing agent of religiosity. According to Brown's (2006) media practice model, adolescents' identity and how they interact with the world should both influence and be influenced by what media adolescents choose. Thereafter, how adolescents engage with media and make meaning from the media is likely to affect their behaviors and worldviews. Given that violent and sexual images are commonly portrayed on multiple sources of media (for a review see Dubow et al. 2007), it is likely that such media content may promote attitudes and values that are in sharp contrast to those espoused within young people's mainstream religious doctrine.

Consistent with these theoretical works, media has been related to religious identity. For example, American emerging adults integrate concepts from nonreligious sources found in movies (e.g., the "force" from Star Wars) with religious doctrine (often from their religious upbringing) to create individualized religious beliefs (Arnett and Jensen 2002). The media may be particularly relevant in the formation of one's religious identity in the absence of other religious socializers as seen by work that found youth with little connection to a religious institution are likely to be influenced by the mass media's depiction of the supernatural in shaping their own religious and spiritual beliefs (Clark 2002). Furthermore, given that religious symbols are present in nearly half of all music videos (Pardun and McKee 1995), adolescents and emerging adults explore their existing religious beliefs and practices through examining traditional symbols as they are portrayed in new ways (e.g., the singer Madonna wearing crucifixes; Beaudoin 1998). Moreover, most college students indicate that listening to music has been associated with religious experiences and discussions (MontgomeryGoodnough and Gallagher 2007). Finally, given the prevalence of video game and Internet usage in emerging adulthood, there is reason to believe they may impact religious development. Indeed, both video game and Internet usage has been related both positively and negatively to adjustment among adolescents as well as emerging adults (e.g., Padilla-Walker et al. 2010; van der Aa et al. 2009), with viewing of pornographic material on the Internet (and in other forms), specifically, being negatively linked to religious practices in a sample of religious college students (Nelson et al. 2010). Taken together, multiple forms of media can and do relate to young people's religiosity, which may promote exploration and religious identity development.

In summary, numerous socialization agents have the potential to shape adolescents' and emerging adults' religiosity. Although parents typically are the primary socialization agents during childhood and to a lesser extent in adolescence, they create the foundation from which adolescents and emerging adults critically explore their beliefs and practices. Peers and media clearly serve a unique role in young people's religious socialization, and more research into the processes by which each agent has the potential to transform young people's beliefs and practices is worthy of further attention.

\section{Variations in Religiosity}

Beyond religious socialization, other factors influence the wide variation that can be seen in the religious lives 
of young people. These factors may (a) lead to differences in the extent to which religious beliefs are developed and the importance placed on those beliefs, (b) influence the way in which such beliefs and practices are socialized, and (c) influence the correlates and outcomes of religiosity. In the following sections, literature is reviewed, albeit in its infancy that evidences the possible roles of culture, communities, and gender in young people's religiosity. First, however, it is important to note the potential role of affiliation.

Affiliation. For many people, "religion" connotes affiliation (currently or in the past or that is held by family members or friends). There is evidence that affiliation alone reflects a great deal of variance. As highlighted earlier in the NSYR data, "a noticeable pattern of religiosity [exists], ranging from Mormons at the high end, to conservative and black Protestants, further down to mainline Protestant and Catholic teens, and then to Jewish and nonreligious teens on the lower end" (Smith and Denton 2005, p. 70).

Clearly religiosity differs by affiliation; however, it is beyond the scope of this essay to review those studies for three reasons. First, there is not space to examine the ways in which various faith traditions socialize their younger members (see Yust et al. 2006 for a review). Second, devout members of any religious tradition are likely to appear more similar to each other than are those within the same religion. Finally, affiliation does not capture the extent to which an individual might immerse oneself in the culture and community of a religious tradition. The latter are more likely than affiliation to capture the rich sources of influence that might account for variation in religious development. Hence, the variations that exist among religious traditions are noted, but instead of focusing on affiliation, this part of the essay will focus on culture and communities as well as gender.

Culture. There is a notable dearth in broad crosscultural comparisons of religiosity within adolescence and emerging adulthood. However, work examining the role of religion within cultures is emerging. First, research has been conducted within various countries as well as subcultures to demonstrate how culture may influence the extent to which beliefs are developed and the importance placed on those beliefs. For instance, African Americans make up a subculture for which religious development appears to be different from the larger American culture. Having long-standing roots of religiosity and spirituality in the AfricanAmerican culture (Boyd-Franklin 2003), African Americans tend to report significantly higher levels of religiosity compared with Caucasians (Taylor et al. 1999).

Culture not only appears to influence the strength of the African-Americans' beliefs, but the role of religiosity as it may play a particularly important cultural function. Compared to those with lower levels of spirituality, when highly spiritual African-American college students perceived their racist encounters as stressful, they did not report lower levels of psychological health (Bowen-Reid and Harrell 2002). Moreover, for African-American women in emerging adulthood racial identity development coincides with greater reliance on religiosity and a more intrinsic religious orientation (Sanchez and Carter 2005). In sum, AfricanAmerican culture may serve as an example of how culture differentially (a) influences the development of religious and spiritual beliefs, (b) impacts the importance placed on those beliefs, and (c) determines the functions those beliefs play in one's life as a result of the culture in which they live.

Next, culture may affect socialization practices, such as how parents socialize young people into belief systems as well as what those belief systems should include. For example, in a study examining the religious socialization for second-generation Asian Americans, Park and Ecklund (2007) found that emerging adults viewed their families, especially their mothers, as the most important socializers of their religious beliefs. However, these young people broadly conceptualized "family" to include not just parents, but also "kin" (e.g., siblings, aunts) who acted as "substitutes in the absence of parental influence, reinforces in concern with them, or contrasts in comparison with them" (p. 99). Familial socialization is prominent because of Confucian doctrine that stresses their obligation to all extended family members. This study evidences the important role that culture may have in religious socialization.

Third, culture may affect the correlates and outcomes of religious development. Controlling for economic status, region of country, and religious affiliation, emerging adults from American ethnicminority cultures such as African-Americans report higher levels of religiosity (both beliefs and practices) than do European Americans (Taylor et al. 1996). 
Moreover, among those African-American college students, higher spiritual and religious salience scores were linked to better health-promoting behaviors (e.g., better nutrition and interpersonal relationships; Bowen-Reid and Smalls 2004).

Future research on the role of culture in religious development must understand the complexity of culture. Many ethnic-minority individuals within a given culture might identify themselves with multiple cultures (e.g., majority culture and their culture of heritage). For instance, Cheah and Nelson (2004) found that Canadian Aboriginal young people who identified more with their culture of heritage rated themselves higher on religious beliefs and attitudes toward obligations to children and family as well as engaged in less drug and alcohol use than did their peers who identified less with their Aboriginal heritage. These findings underscore the need for scholars to explore the role of acculturation when examining the function that competing cultures may have on the correlates of religiosity.

Community. Beyond the contextual influences of culture, other contextual influences exist as well, such as communities, which may adhere to and promote particular religious beliefs and practices. Communities may take the form of being specifically devoted toward religious development (e.g., congregational youth group), unrelated to religion directly (e.g., university, work place), or a combination of religious and secular development (e.g., a religious high school). Affiliation with a community has been shown to influence (a) the extent to which religious beliefs are developed and the importance placed on those beliefs, (b) the way in which such beliefs and practices are socialized, and (c) the correlates and outcomes of religiosity.

Schools may provide a community that can have either positive or negative effects on young people. For example, if their school consists of a rather religiously homogenous community of peers such as what might exist in parts of the southern USA (which tends to have a high population of Baptists) then youth may be able to be more open in their religious expressions as well as avoid ridicule for their particular beliefs. For example, Smith and Denton (2005) found that most American adolescents (78\%) feel fairly free to express their religiosity at school compared to only $18 \%$ feeling that other students at school generally look down on teens who are openly religious and only $23 \%$ who did not feel they could openly express one's faith at school.
What these statistics are unable to capture, however, is how these numbers change in light of an adolescent being in the minority or majority as far as the school community's religious diversity. Regnerus et al. (2004) provide evidence that the school's (not just friendship network) average level of importance of religion and church attendance were positively related to individual students' religious attendance and subjective importance of religion. Furthermore, research shows that when religious diversity is low, norms and sanctions may have more influence over individual religious choices (Ellison 1995). Finally, an individual's public religiosity has been linked to the religiosity of the school (e.g., a higher percentage of students in one's school with the same religious affiliations, popular students in the school are more religious; Barrett et al. 2007). Taken together, the existing research shows a clear picture that the school community - not just the immediate peer (friendship) group - provides an important context for religious development.

A similar situation appears to exist in higher education. College, a "community" common to a subset of emerging adults both socializes and desocializes students (Feldman and Newcomb 1969). Particularly for residential students, the university setting merges numerous contexts (e.g., peer, work, academic), such that the college community is likely to influence religious and especially spiritual beliefs and values, especially in the first year (Braskamp 2008). Like high school, however, the impact of the college community may differ depending on its type. For example, admission to some religious institutions of higher education is contingent upon one's willingness to commit to live by a code of conduct regulating one's dress, appearance, and behaviors (e.g., abstaining from drugs and premarital sex). Research supports the notion that such community standards and practices influence the religious development of emerging adults. For instance, compared to their peers at other institutions, young people attending a Mormon university differed in their beliefs (e.g., higher levels or spirituality and religious practices), attitudes (e.g., what characteristics are needed to achieve adulthood and the extent to which they felt they had achieved those characteristics), and behaviors (e.g., less drug and alcohol use, Barry and Nelson 2005).

In sum, the findings suggest that the structure or type of community may lead to different outcomes for 
young people. For some, the community may foster exploration of religious beliefs, leading some young people into new paths compared to those in which they were raised (Markstrom-Adams et al. 1994). Other educational communities may foster adoption rather than exploration of beliefs. Regardless, these educational communities appear to matter in young people's religious lives.

Another type of community that may influence one's religious development is a faith community. Religious affiliations not only provide the context for the teaching of specific doctrines and participation in religious practices and rituals, they also provide the opportunity for membership in a community. While acknowledging that religious beliefs, values, and norms could also easily be characterized as a culture, a distinction is made here between culture and faith communities because membership within a religious community may have direct effects on a person's religiosity via the processes by which the community socializes an individual into its beliefs and practices. Indeed, Roehlkepartain and Patel (2006) present a conceptual model of the ways in which congregations provide a setting for religious and spiritual development. Specifically, congregations provide (a) sacred symbols and space (e.g., the cross); (b) relationships; (c) environment and climate (e.g., warmth); (d) beliefs, values, and standards; (e) worship, rituals, and ceremonies (e.g., daily prayers, music, sacraments); (f) educational, social, and leadership opportunities (e.g., youth groups, missions, Bible study groups); and (g) policies and processes (e.g., how decisions are made, resources used in religious education).

While there is ample evidence that different faith communities socialize in similar and unique ways across world religious traditions, see Yust et al. (2006) for a review, there is a paucity of research examining how socialization practices varying by faith communities are linked directly to young people's religious and spiritual attitudes, beliefs, and behaviors specifically. Scholars should utilize the Roehlkepartain and Patel model (2006) for further work on how communities socialize adolescents and emerging adults.

Furthermore, there is a need to examine how socialization processes may be linked to different outcomes. Religious affiliation has been linked in large, nationally representative samples of American adults to outcomes such as timing of first marriage (Xu et al. 2005) and divorce rates (Mullins et al. 2006). Thus, it follows that various faith communities provide different emphases and structure that develop belief systems, values, and behaviors (see Yust et al. 2006) that may be differently linked to developmental outcomes (e.g., marital satisfaction; Mahoney and Tarakeshwar 2005). As a result, scholars need to go beyond just examining how affiliation with a particular community is tied to different beliefs and behaviors and begin to investigate the specific pathways and processes by which affiliation with a community leads to different outcomes. Moreover, scholars need to examine the role that neighborhood settings and other communities (e.g., military) have in shaping young people's religious development. Finally, religiosity has been related to adolescents' ties to their broader community (Good and Willoughby 2007); therefore, scholars should examine the bidirectional nature of religiosity and connection to communities.

Gender. Gender also may lead to differences in the extent to which religious beliefs are developed and the importance placed on those beliefs. Specifically, Smith and Denton (2005) found adolescent girls to attend religious services more frequently, to place greater importance of religious faith in shaping daily life, to have committed personally to live life for God, to participate in a religious youth group, to pray alone more frequently, and to feel closer to God than do boys. Similarly, among emerging adults, researchers have found that women engage in more religious practices (Loewenthal et al. 2001), and have greater levels of belief in God (Barry and Nelson 2005) than do men.

Second, gender may influence the way in which such beliefs and practices are socialized given that parental influences on gender socialization begin upon a child's birth (Stern and Karraker 1989). While research on gender differences in the socialization of religion by parents is almost nonexistent, parents even as late as emerging adulthood hold different beliefs and expectations for sons than daughters. For example, Nelson et al. (2007) found that mothers and fathers rated various criteria for adulthood differently depending on the gender of their child. The findings suggest that parents may socialize their sons and daughters differently, thereby underscoring the need for future research both within the USA and worldwide given the varying degree of traditional gender roles that are socialized within and across cultures. 
Finally, the correlates and outcomes of religiosity appear to differ based on gender. Scholars either have documented gender differences (e.g., Loewenthal et al. 2001) or controlled for gender (Lefkowitz et al. 2004); however, they rarely have examined the interaction of gender and religiosity on other developmental outcomes despite emerging evidence that such interactions exist. For example, in adolescence, Miller and Hoffman (1995) found that the relation between risk preference and religiosity differs by gender. In emerging adulthood, Barry and Nelson (2008) found that religiosity (particularly for moderate levels) provides an integral role in American women's self-development, but not in men's. Future research should explore other ways in which religion may be differentially linked to developmental processes and outcomes for each gender.

Summary and caution. The literature has shown how culture, communities, and gender may influence religiosity concerning (a) the extent to which beliefs and practices are developed and the importance placed on those beliefs, (b) how they are socialized, and (c) their correlates and related outcomes. While the prevalence of research links religiosity to adjustment positively, some religious socialization practices are negative. For example, some socializers of religion (e.g., parents, religious communities) have invoked God or religion in ways that harm children (e.g., withholding medical treatment, abuse, coercion; Mahoney et al. 2003), or promote hatred against particular ethnic groups, religions, gender, or sexual minorities (e.g., Kubicek et al. 2009). In sum, despite the clear benefits of religious development, young people also can be influenced negatively, even extremely so, by those who are socializing the darker side of religion (e.g., bigotry) or who in the name of religion are bringing harm to children.

\section{Future Research Directions}

Thanks to the Society for Research in Child Development preconference on religious and spiritual development as well as the increasing presence of American Psychological Association's Psychology of Religion Division (\#36), scholarship on adolescent and emerging-adult religiosity is steadily increasing albeit slowly. In order to increase their understanding not only quantitatively, but also qualitatively in this topic, scholars should consider the following recommendations. First, greater precision in definitions for and measurement of religious beliefs and practices is needed so that they are conceptually distinct from spiritual beliefs and practices. Second, scholars should investigate the relations among physiological (especially brain development), cognitive, and psychosocial development with the development of religiosity more directly. Third, although there are notable studies of representative samples of adolescents, there is a dearth of representative samples of emerging adults, especially those not attending institutions of higher education. Fourth, scholars should examine the interrelation between religious and spiritual beliefs and practices to understand more fully those young people who are spiritual, but not religious. Fifth, scholars should theorize more about the development and socialization of religious conceptualizations. Sixth, scholars should investigate how the multiple contexts in which young people are embedded socialize religiosity as well as the variations that exist within and between cultures, communities, and genders. Lastly, all of these research directions can benefit from sequential designs to examine cohort differences and developmental trajectories of religiosity from adolescence through their transition to adulthood.

\section{Conclusion}

This essay has demonstrated that adolescence and emerging adulthood mark seminal periods of development for an individual's religious identity due to the unique biological, cognitive, and psychosocial changes. The process by which young people are socialized into their religious development and what happens as they transition to adulthood is clearly complex given their increasing autonomy and identity exploration. Moreover, religious development has been shown to have implications for young people's individual adjustment and well-being as well as their relationships. Unfortunately, religious development among adolescents and emerging adults has received much less attention by scholars than other domains of development (Levenson et al. 2005). The plethora of emerging evidence presented here suggests that this domain can no longer be ignored if scholars hope to understand critical aspects of development in adolescence and emerging adulthood fully.

\section{Cross-References}

$\checkmark$ Faith 


\section{References}

Arnett, J. J. (2004). Emerging adulthood: The winding road from the late teens through the twenties. New York: Oxford University Press.

Arnett, J. J., \& Jensen, L. A. (2002). A congregation of one: Individualized religious beliefs among emerging adults. Journal of Adolescent Research, 17, 451-467.

Astin, A. W., Astin, H. S., Lindolm, J. A., Bryant, A. N., Calderon, S., \& Szelényi, K. (2005a). The spiritual life of college students: A national survey of college students' search for meaning and purpose. Los Angeles: Higher Education Research Institute.

Astin, A. W., Astin, H. S., Lindolm, J. A., Bryant, A. N., Calderon, S., \& Szelényi, K. (2005b). Spirituality and the professoriate: A national study of faculty beliefs, attitudes, and behaviors. Los Angeles: Higher Education Research Institute.

Bao, W., Whitbeck, L. B., Hoyt, D. R., \& Conger, R. D. (1999). Perceived parental acceptance as a moderator of religious transmission among adolescents and boys. Journal of Marriage and the Family, 61, 362-374.

Barrett, J. B., Pearson, J., Muller, C., \& Frank, K. (2007). Adolescent religiosity and school contexts. Social Science Quarterly, 88, 1024-1037.

Barry, C. M., Madsen, S. D., Nelson, L. J., Carroll, J. S., \& Badger, S. (2009). Friendship and romantic relationship qualities in emerging adulthood: Differential association with progress on identity development and societal tasks. Journal of Adult Development, 16, 209-222.

Barry, C. M., \& Nelson, L. J. (2005). The role of religion in the transition to adulthood for young emerging adults. Journal of Youth and Adolescence, 34, 245-255.

Barry, C. M., \& Nelson, L. J. (2008). The role of religious beliefs and practices on emerging adults' perceived competencies, perceived importance ratings, and global self-worth. International Journal of Behavioral Development, 32, 509-521.

Barry, C. M., \& Wentzel, K. R. (2006). Friend influence on prosocial behavior: The role of motivational factors and friendship characteristics. Developmental Psychology, 42, 153-163.

Beaudoin, T. (1998). Virtual faith: The irreverent spiritual quest of Generation X. San Francisco: Jossey-Bass.

Beyers, W. C. J., \& Seiffge-Krenke, I. (2008, March). Does identity precede intimacy? An Eriksonian approach to romantic development in emerging adulthood. Paper presented at the biennial meeting of the Society of Research in Adolescence, Chicago.

Bowen-Reid, T. L., \& Harrell, J. P. (2002). Racist experiences and health outcomes: An examination of spirituality as a buffer. Journal of Black Psychology, 28, 18-36.

Bowen-Reid, T. L., \& Smalls, C. (2004). Stress, spirituality and health promoting behaviors among African American college students. The Western Journal of Black Studies, 28, 283-291.

Boyd-Franklin, N. (2003). Black families in therapy: An AfricanAmerican experience (2nd ed.). New York: Guilford.

Braskamp, L. A. (2008). The religious and spiritual journeys of college students. In D. Jacobsen \& R. H. Jacobsen (Eds.), The American university in a postsecular age (pp. 117-134). New York: Oxford University Press.
Brelsford, G. M., \& Mahoney, A. (2008). Spiritual disclosure between older adolescents and their mothers. Journal of Family Psychology, 22(1), 62-70.

Brown, J. D. (2006). Emerging adults in a media-saturated world. In J. J. Arnett \& J. L. Tanner (Eds.), Emerging adults in America: Coming of age in the 21st century (pp. 279-299). Washington, DC: APA.

Cannister, M. W. (1999). Mentoring and the spiritual well-being of late adolescents. Adolescence, 34, 769-779.

Caputo, R. K. (2004). Parent religiosity, family processes and adolescent outcomes. Families in Society, 85, 495-510.

Carbery, J., \& Buhrmester, D. (1998). Friendship and need fulfillment during three phases of young adulthood. Journal of Social and Personal Relationships, 15, 393-409.

Cheah, C. S. L., \& Nelson, L. J. (2004). The role of acculturation in the emerging adulthood of Aboriginal college students. International Journal of Behavioral Development, 28, 495-507.

Clark, L. (2002). U.S. adolescent religious identity, the media, and the "funky" side of religion. The Journal of Communication, 52(4), 794-811.

De Vaus, D. A. (1983). The relative importance of parents and peers for adolescent religious orientation: An Australian study. Adolescence, 18, 147-158.

Dollahite, D. C., \& Thatcher, J. Y. (2008). Talking about religion: How religious youth and parents discuss their faith. Journal of Adolescent Research, 23, 611-641.

Dorn, L., Dahl, R., Woodward, H., \& Biro, F. (2006). Defining the boundaries of early adolescence: A user's guide to assessing pubertal status and pubertal timing in research with adolescents. Applied Developmental Science, 1, 30-56.

Dubow, E. F., Huesmann, L. R., \& Greenwood, D. (2007). Media and youth socialization: Underlying processes and moderators of effects. In J. E. Grusec \& P. D. Hastings (Eds.), Handbook of socialization: Theory and research (pp. 404-430). New York: Guilford.

Duriez, B., Smits, I., \& Goossens, L. (2008). The relation between identity styles and religiosity in adolescence: Evidence from a longitudinal perspective. Personality and Individual Differences, 44(4), 1022-1031.

Eaves, L. J., Hatemi, P. K., Prom-Womley, E. C., \& Murrelle, L. (2008). Social and genetic influences on adolescent religious attitudes and practices. Social Forces, 86, 1621-1646.

Elkind, D. (1971). The development of religious understanding in children and adolescents. In M. P. Strommen (Ed.), Research on religious development (pp. 655-685). New York: Hawthorn Books.

Elkind, D. (1978). Understanding the young adolescent. Adolescence, $13,127-134$.

Ellison, C. (1995). Rational choice explanations of individual religious behavior-notes on the problem of social embeddedness. Journal of Scientific Study of Religion, 34, 89-120.

Feldman, K., \& Newcomb, T. (1969). The impact of college on students. San Francisco: Jossey-Bass.

Finlay, A. K., Flanagan, C., \& Black, S. (2007). Service as a developmental opportunity: Building connections for vulnerable youths. Saint Paul, MN: National Youth Leadership Council. 
Finlay, B., \& Walther, C. S. (2003). The relation of religious affiliation, service attendance, and other factors to homophobic attitudes among university students. Review of Religious Research, 44(4), 370-393.

Flor, D. L., \& Knapp, N. F. (2001). Transmission and transaction: Predicting adolescents' internalization of parental religious values. Journal of Family Psychology, 15(4), 627-645.

Fowler, J. W. (2001). Faith development theory and the postmodern challenges. International Journal for the Psychology of Religion, 11, 159-172.

Fowler, J. W., \& Dell, M. L. (2006). Stages of faith from infancy through adolescence: Reflections on three decades of faith development theory. In E. C. Roehlkepartain, P. E. King, L. Wagener, \& P. L. Benson (Eds.), The handbook of spiritual development in childhood and adolescence (pp. 34-45). Thousand Oaks: Sage.

Gallup, G., Jr., \& Casteli, J. (1989). The people's religion. New York: Macmillan.

Good, M., \& Willoughby, T. (2007). The identity formation experiences of church-attending rural adolescents. Journal of Adolescent Research, 22, 387-412.

Granqvist, P., \& Hagekull, B. (1999). Religiousness and perceived childhood attachment: Profiling socialized correspondence and emotional compensation. Journal for the Scientific Study of Religion, 38, 254-273.

Granqvist, P., \& Kirkpatrick, L. A. (2004). Religious conversion and perceived childhood attachment: A meta-analysis. The International Journal for the Psychology of Religion, 14(4), 223-250.

Gunnoe, M. L., \& Moore, K. A. (2002). Predictors of religiosity among youth aged 17-22: A longitudinal study of the National Survey of Children. Journal for the Scientific Study of Religion, 41, 613-622.

Hoge, D., Johnson, B., \& Luidens, D. A. (1993). Determinants of church involvement of young adults who grew up in Presbyterian churches. Journal of the Scientific Study of Religion, 32, 242-255.

Inglehart, R., Basaňez, M., Díez-Medrano, J., Halman, L., \& Luijkx, R. (2004). Human beliefs and values: A cross-cultural sourcesbook based upon the 1999-2002 values surveys. Mexico City: Siglo Veintiuno Editores.

Kirkpatrick, L. A. (1995). Attachment theory and religious experience. In R. W. Hood Jr. (Ed.), Handbook of religious experience (pp. 446-475). Birmingham, AL: Religious Education Press.

Koenig, H. G., McCullough, M. E., \& Larson, D. B. (2001). Handbook of religion and health. New York: Oxford University Press.

Koenig, L. B., McGue, M., \& Iacono, W. G. (2008). Stability and change in religiousness during emerging adulthood. Developmental Psychology, 44, 532-543.

Kubicek, K., McDavitt, B., Carpineto, J., Weiss, G., Iverson, E. F., \& Kipke, M. D. (2009). "God made me gay for a reason": Young men who have sex with men's resiliency in resolving internalized homophobia from religious sources. Journal of Adolescent Research, 24, 601-633.

Labouvie-Vief, G. (2006). Emerging structures of adult thought. In J. J. Arnett \& J. L. Tanner (Eds.), Emerging adults in America: Coming of age in the 21st century (pp. 59-84). Washington, DC: American Psychological Association.
Larson, R., \& Richards, M. H. (1991). Daily companionship in late childhood and early adolescence: Changing developmental contexts. Child Development, 62, 284-300.

Lee, J. J. (2002). Religion and college attendance: Change among students. The Review of Higher Education, 25, 369-384.

Lefkowitz, E. S., Boone, T. L., \& Shearer, C. L. (2004). Communication with best friends about sex-related topics during emerging adulthood. Journal of Youth and Adolescence, 33, 339-351.

Levenson, M. R., Aldwin, C. M., \& D’Mello, M. (2005). Religious development from adolescence to middle adulthood. In R. F. Paloutzian \& C. L. Park (Eds.), Handbook of the psychology of religion and spirituality (pp. 144-161). New York: Guilford.

Levesque, R. J. R. (2002). Not by faith alone: Religion, law, and adolescence. New York: New York University Press.

Loewenthal, K. M., MacLeod, A. K., \& Cinnirella, M. (2001). Are women more religious than men? Gender differences in religious activity among different religious groups in the UK. Personality and Individual Differences, 32, 133-139.

Loser, R. W., Hill, E. J., Klein, S. R., \& Dollahite, D. C. (2009). Perceived benefits of religious rituals in the Latter-day Saint home. Review of Religious Research, 50(3), 345-362.

Mahoney, A., Pargament, K. I., Murray-Swank, A., \& Murray-Swank, N. (2003). Religion and the sanctification of family relationships. Review of Religious Research, 44, 220-236.

Mahoney, A., Pargament, K. I., Tarakeshwar, N., \& Swank, A. (2001). Religion in the home in the 1980s and 90s: A meta-analytic review and conceptual analysis of religion, marriage, and parenting. Journal of Family Psychology, 15, 559-596.

Mahoney, A., \& Tarakeshwar, N. (2005). Religion's role in marriage and parenting in daily life and during family crises. In R. F. Paloutzian \& C. L. Park (Eds.), Handbook of the psychology of religion and spirituality (pp. 177-195). New York: Guilford.

Markstrom-Adams, C., Hofstra, G., \& Dougher, K. (1994). The egovirtue of fidelity: A case for the study of religion and identity formation in adolescence. Journal of Youth and Adolescence, 23, 453-469.

Meeus, J., Iedema, J., Helsen, M., \& Vollebergh, W. (1999). Patterns of adolescent identity development: Review of literature and longitudinal analysis. Developmental Review, 19, 419-461.

Milevsky, A., \& Leh, M. (2008). Religiosity in emerging adulthood: Familial variables and adjustment. Journal of Adult Development, $15,47-53$.

Milevsky, A., Smooth, K., Leh, M., \& Ruppe, A. (2005). Familial and contextual variables and the nature of sibling relationships in emerging adulthood. Marriage \& Family Review, 37(4), 123-141.

Miller, A. S. (2000). Going to hell in Asia: The relationship between risk and religion in a cross cultural setting. Review of Religious Research, 42(1), 5-18.

Miller, A. S., \& Hoffman, J. P. (1995). Risk and religion: An explanation of gender differences in religiosity. Journal for the Scientific Study of Religion, 34, 63-75.

Miller, W. R., \& Thoresen, C. E. (2003). Spirituality, religion, and health: An emerging research field. The American Psychologist, 58, $24-35$. 
Moberg, D. O. (2002). Assessing and measuring spirituality: Confronting dilemmas of universal and particular evaluative criteria. Journal of Adult Development, 9, 47-60.

Montgomery-Goodnough, A., \& Gallagher, S. J. (2007). Review of research on spiritual and religious formation in higher education. In S. M. Nielsen \& M. S. Plakhotnik (Eds.), Proceedings of the sixth annual college of education research conference: Urban and international education section (pp. 60-65). Miami: International University. http://coeweb.fiu.edu/research_conference/.

Mullins, L. C., Brackett, K. P., Bogie, D. W., \& Pruett, D. (2006). The impact of concentrations of religious denominational affiliations on the rate of currently divorced in counties in the United States. Journal of Family Issues, 27, 976-1000.

Nelson, H. M. (1990). The religious identification of children of interfaith marriages. Review of Religious Research, 32, 122-134.

Nelson, L. J., \& Barry, C. M. (2005). Distinguishing features of emerging adulthood: The role of self-classification as an adult. Journal of Adolescent Research, 20, 242-262.

Nelson, L. J., Padilla-Walker, L. M., \& Carroll, J. S. (2010). "I believe it is wrong but I still do it": A comparison of religious young men who do versus do not use pornography. Psychology of Religion and Spirituality, 2(3), 136-147.

Nelson, L. J., Padilla-Walker, L. M., Carroll, J. S., Madsen, S. D., Barry, C. M., \& Badger, S. (2007). "If you want me to treat you like an adult, start acting like one!" Comparing the criteria for adulthood among emerging adults and their parents. Journal of Family Psychology, 21, 665-674.

O’Connor, T. P., Hoge, D. R., \& Alexander, E. (2002). The relative influence of youth and adult experiences on personal spirituality and church involvement. Journal for the Scientific Study of Religion, 41, 723-732.

Oman, D., \& Thoresen, C. E. (2003). Spiritual modeling: A key to spiritual and religious growth. International Journal for the Psychology of Religion, 13, 149-166.

Padilla-Walker, L. M., Nelson, L. J., Carroll, J. S., \& Jensen, A. C. (2010). More than just a game: Video games, internet use, and health outcomes in emerging adults. Journal of Youth and Adolescence, 39, 103-113.

Paloutzian, R. F. (1996). Invitation to the psychology of religions (2nd ed.). Needham Heights: Allyn \& Bacon.

Pardun, C., \& McKee, K. (1995). Strange bedfellows: Symbols of religion and sexuality on MTV. Youth \& Society, 26, 438-449.

Park, J. Z., \& Ecklund, E. H. (2007). Negotiating continuity: Family and religious socialization for second-generation Asian Americans. The Sociological Quarterly, 48, 93-118.

Park, J. Z., \& Smith, C. (2000). “To whom much has been given. ..”: Religious capital and community voluntarism among churchgoing Protestants. Journal for the Scientific Study of Religion, 29(3), 272-286.

Perry, W. G., Jr. (1981). Cognitive and ethical growth. In A. Chickering (Ed.), The modern American college (pp. 76-116). San Francisco: Jossey Bass.

Puffer, K. A., Pence, K. G., Graverson, T. M., Wolfe, M., Pate, E., \& Clegg, S. (2008). Religious doubt and identity formation: Salient predictors of adolescent religious doubt. Journal of Psychology and Theology, 36(4), 270-284.

Regnerus, M. D., \& Smith, C. (2005). Selection effects in studies of religious influence. Review of Religious Research, 47(1), 23-50.

Regnerus, M., Smith, C., \& Smith, B. (2004). Social context in the development of adolescent religiosity. Applied Developmental Science, 8, 27-38.

Rew, L., \& Wong, Y. J. (2006). A systematic review of associations among religiosity/spirituality and adolescent health attitudes and behaviors. The Journal of Adolescent Health, 38, 433-442.

Roberts, D. F., Foehr, U. G., Rideout, V. J., \& Brodie, M. (1999). Kids \& media@ the new millennium: A comprehensive national analysis of children's media use. Menlo Park: Henry J. Kaiser Family Foundation.

Roehlkepartain, E. C., \& Patel, E. (2006). Congregations: Unexamined crucibles for spiritual development. In E. C. Roehlkepartain, P. E. King, L. Wagener, \& P. L. Benson (Eds.), The handbook of spiritual development in childhood and adolescence (pp. 324-336). Thousand Oaks: Sage.

Sanchez, D., \& Carter, R. T. (2005). Exploring the relationship between racial identity and religious orientation among African American college students. Journal of College Student Development, 46, 280-295.

Sanders, J. L. (1998). Religious ego identity and its relationship to faith maturity. The Journal of Psychology, 132, 653-658.

Schwartz, K. D. (2006). Transformations in parent and friend faith support predicting adolescents' religious faith. The International Journal for the Psychology of Religion, 16, 311-326.

Silberman, I. (2003). Spiritual role modeling: The teaching of meaning systems. International Journal for the Psychology of Religion, 13, 175-195.

Smith, C., \& Denton, M. L. (2005). Soul searching: The religious and spiritual lives of American teenagers. New York: Oxford University Press.

Smith, C., \& Snell, P. (2009). Souls in transition: The religious and spiritual lives of emerging adults. New York: Oxford University Press.

Solomontos-Kountouri, O., \& Hurry, J. (2008). Political, religious and occupational identities in context: Placing identity status paradigm in context. Journal of Adolescence, 31(2), 241-258.

Sowell, E. R., Trauner, D. A., Gamst, A., \& Jernigan, T. L. (2002). Development of cortical and subcortical brain structures in childhood and adolescence: A structural MRI study. Developmental Medicine and Child Neurology, 44, 4-16.

Steinberg, L. (2005). Cognitive and affective development in adolescence. Trends in Cognitive Sciences, 9, 69-74.

Stern, M., \& Karraker, K. H. (1989). Sex stereotyping of infants: A review of gender labeling studies. Sex Roles, 20, 501-522.

Stolzenberg, R. M., Blair-Loy, M., \& Waite, L. J. (1995). Religious participation in early adulthood: Age and family life cycle effects on church membership. American Sociological Review, 60, 84-103.

Tamminen, K. (1994). Comparing Oser's and Fowler's developmental stages. Journal of Empirical Theology, 7, 75-112. 
Taylor, R. J., Chatters, L. M., Jayakody, R., \& Levin, J. S. (1996). Black and white differences in religious participation: A multisample comparison. Journal for the Scientific Study of Religion, 35, 403-410.

Taylor, R. J., Mattis, J. S., \& Chatters, L. (1999). Subjective religiosity among African-Americans: A synthesis of findings from five national samples. Journal of Black Psychology, 25, 524-543.

Torney-Purta, J., Lehmann, R., Oswald, H., \& Schulz, W. (2001). Citizenship and education in twenty-eight countries: Civic knowledge and engagement at age fourteen. Amsterdam: International Association for the Evaluation of Educational Achievement.

Uecker, J. E., Regnerus, M. D., \& Vaaler, M. E. (2007). Losing my religion: The social sources of religious decline in early adulthood. Social Forces, 85, 1667-1692.

Van der Aa, N., Overbeek, G., Engels, R. C. M. E., Scholte, R. H. J., Meerkerk, G. J., \& Van den Eijnden, R. J. J. M. (2009). Daily and compulsive internet use and well-being in adolescence: A diathesis-stress model based on big five personality traits. Journal of Youth and Adolescence, 38(6), 765-776.

Wagener, L. M., Furrow, J. L., King, P. E., Leffert, N., \& Benson, P. (2003). Religious involvement and developmental resources in youth. Review of Religious Research, 44(3), 271-284.

Walker, E. F., Sabuwalla, Z., \& Huot, R. (2004). Pubertal neuromaturation, stress sensitivity, and psychopathology. Development and Psychopathology, 16, 807-824.

Waterman, A. S. (1985). Identity in the context of adolescent psychology. In A. S. Waterman (Ed.), New directions for child development: Identity in adolescence: Processes and contents, 30 (pp. 5-24). San Francisco: Jossey-Bass.

White, H. R., McMorris, B. J., Catalano, R. F., Fleming, C. B., Haggerty, K. P., \& Abbott, R. D. (2006). Increases in alcohol and marijuana use during the transition out of high school into emerging adulthood: The effects of leaving home, going to college, and high school protective factors. Journal of Studies on Alcohol, 67, 810-822.

Xu, X., Hudspeth, C. D., \& Bartowski, J. P. (2005). The timing of first marriage: Are there religious variations? Journal of Family Issues, 26, 584-618.

Young, J. S., Cashwell, C. S., \& Shcherbakova, J. (2000). The moderating relationship of spirituality on negative life events and psychological adjustment. Counseling and Values, 45, 49-57.

Yust, K. M., Johnson, A. N., Sasso, S. E., \& Roehlkepartain, E. C. (2006). Nurturing child and adolescent spirituality: Perspectives from the world's religious traditions. Lanham: Rowman \& Littlefield.

Zaleski, E. H., \& Schiaffino, K. M. (2000). Religiosity and sexual risktaking behavior during the transition to college. Journal of Adolescence, 23, 223-227.

Zinnbauer, B. J., \& Pargament, K. I. (2005). Religiousness and spirituality. In R. F. Paloutzian \& C. L. Park (Eds.), Handbook of the psychology of religion and spirituality (pp. 21-42). New York: Guilford.

Zinnbauer, B. J., Pargament, K. I., \& Scott, A. B. (1999). The emerging meanings of religiousness and spirituality: Problems and prospects. Journal of Personality, 67, 889-919.

\section{Religious Expression Rights}

\author{
Roger J. R. LeVesque \\ Indiana University, Bloomington, IN, USA
}

Jurisprudence addressing adolescents' rights to religious expressions, especially the right not to express a religious conviction not their own, dates back to the foundational cases dealing with adolescents' rights. This is not surprising given that one of the most important rights involving adolescents is their right to be able to hold beliefs and not be required to express or internalize beliefs that are anathema to their sense of self. In law, that right is most closely related to the freedom of religion, which protects individuals from imposed orthodoxies. Adolescents' rights, however, are quite limited. Their religious rights tend to be controlled by adults. Despite that general rule, there is some movement toward respecting their own, individual rights to religion. That movement, however, remains strikingly limited and underdeveloped, especially when viewed in light of other developments in adolescents' rights that relate, for example, to their privacy and relationships (see Levesque 2000). This essay examines key cases and themes emerging in United States' jurisprudence relating to adolescents' rights to religious expression (for a broader review, see Levesque 2002).

One of the most important cases involving adolescents' rights is West Virginia State Board of Education v. Barnette (1943), a case in which the Court recognized the importance of protecting students' First Amendment rights in the primary and secondary school setting. The right in question directly involved religious beliefs. In Barnette, members of a Jehovah's Witness congregation, on behalf of children in public schools in West Virginia, challenged a state law requiring all students to salute the flag and recite the pledge of allegiance. The Jehovah's Witnesses argued that the state regulation conflicted with their religious beliefs and improperly subjected children, including their own children, to possible exclusion from school. The Court held that requiring schoolchildren to salute the United States flag violated the First Amendment by compelling "affirmation of a belief and an attitude of mind" (West Virginia State Board of Education v. 